\title{
Underground and Opencast Coal Mining Methods in India: A Comparative Assessment
}

Sourav Mukherjee ${ }^{+*}$ and Dr Deb Prakash Pahari ${ }^{1}$

\section{Abstract}

Coal is one of the most essential resources of a country. It is widely used for power generation and as a raw material in the industries. India ranks third in coal production. However, the country has to import coal in order to meet the rising demand for coal. In India, coal mining is conducted using two methods: underground and opencast methods. The underground method is suitable for extraction of deeper coal seams, whereas opencast method is suitable for shallow coal seams. However, due to less production cost, mechanisation, and less wastage, opencast method dominates in India (93.26\% of the total production in the financial year 2016-17). Underground coal production in India shows a declining trend, and several underground mines are closed every year. However, $60 \%$ of the total coal production in the world is from underground mines, whereas in India it constitutes only $6.74 \%$ in the financial year 2016-17. Thus, underground coal production in India is declining. Due to the large scale extraction of near-surface coal resources by opencast mining, near-surface coal resources will be depleted in future.

Moreover, opencast mining has several environmental impacts, which is ignored keeping in view the colossal coal demand of the country. Thus, coal production in India is facing a crisis concerning the production method, environmental impacts and future demand for coal. With this background, this paper has been prepared on the basis of data collected from reports, research papers, and articles. Here, we make an attempt to compare both the mining methods with respect to advantages, disadvantages, environmental impact and feasibility. We also discuss the current and future trends of coal production using both the mining methods. Measures to sustain coal production in India are discussed in the conclusion part.

Keywords: Coal Mining, Underground Mining, Opencast Mining, Environmental Impact, Coal Demand, India

\footnotetext{
${ }^{+}$Research Scholar (UGC-SRF), Dept. of Geography, The University of Burdwan, Burdwan: 713104, West Bengal, India ${ }^{*}$ Corresponding Author, Email: mukherjee824@gmail.com

Î Scientific Officer, Dept. of Geography, The University of Burdwan, Burdwan: 713104, West, Bengal, India. Email :debprakashpahari@gmail.com

(C) 2019 Mukherjee and Pahari. This is an Open Access article distributed under the terms of the Creative Commons Attribution License (http://creativecommons.org/licenses/by/2.0), which permits unrestricted use, distribution, and reproduction in any medium, provided the original work is properly cited.
} 


\section{Introduction}

Coal, as a conventional source of energy, plays a very vital role in the overall economic development of a country. Coal plays a critical role in our economy, as $45 \%$ of the total energy consumption in India is met by coal (Energy Statistics, 2017). Indian economy is facing massive energy demand due to the rising growth of population, industry and other infrastructures. Coal-based power plants meet a major portion of this total energy demand in the country. It is also a major driving force for the industrial revolution, and still, it contributes to the industrial sector as a significant source of energy and raw material. A major consumer of coal in India is the thermal power sector, steel, cement, sponge-iron, aluminium, fly ash bricks, paper, textile, and other small industries. Development of an industrial unit or industrial agglomeration depends on the availability of coal to a large extent. Coal is also used as a source of fuel in households. Countries like India, where the availability of petroleum is deficient and confined, coal plays a vital role in overall economic development. The importance of coal is not only confined in the energy sector but the more significant role it plays in the economy of the country (Coal Vision, 2030a).

The Government of India targeted 1.5 BT of coal production by financial year (FY) 2020 (Tongia, 2016a). Demand for coal in power plants in India is increasing at a faster rate since the 1970s (Chikkatur, 2008a). India ranks third in coal production with a total production of 657.868 million tonnes (Coal Directory of India, 201617a). Though India ranks third in coal production, the gap between demand and supply is so vast that, India has to import coal to meet the rising demand. The gap between supply and demand for coal was 89.913 million tonnes during the FY 2016-17 (Coal Directory of India, 2016-17b). Demand for coal in India as a source of energy will increase up to 2030 and maybe beyond that (Coal Vision, 2030b). In FY 2016-17, India imported 41.644 million tonnes of coking coal and 149.309 million tonnes of noncoking coal. Thus, coal production in India witnessed a massive demand, and domestic production is not sufficient to meet the rising demand. Against this background, the central objective of this research is:

- To present a conceptual background about the OC and UG mining methods in India.

- To make a comparative assessment of significant advantages, disadvantages and environmental impacts of both UG and $O C$ mining methods in the Indian scenario.

- To analyse the overall problems, and suggest suitable measures.

\section{Methodology}

As far as the methodology of this research is concerned, it is mainly based on various secondary data sources such as reports, papers, and articles. Reports about coal production in India were collected from online sources. To analyse the impacts of $O C$ and UG mining methods on the environment, different papers and articles were studied. Past production and current trend of coal production in India was obtained from Provisional Coal Statistics (201213 to 2016-17), Coal Directory of India (2007-08 to 2016-17d), Coal Vision 2030 by Stakeholders' consultation and Indian Coal and Lignite Resources-2017, published by Geological Survey of India have been used to analyse the scenario of coal mining in India.

\section{Coal Mining Methods in Major Coal Producing Countries}

Presently, $60 \%$ of the total coal production in the world is extracted through the UG method (The Coal Resource: A Comprehensive Overview of Coal, 2009)

In the United States, surface mining contributed $66 \%$ of the total production in 2015 (Coal Mining in the United States, 2018). Further, in Australia, $77 \%$ of the total black coal production is extracted by surface mining (Mitra and Saydam, 2012a). The scenario of coal mining for Russia is not very different, where opencast mining contributes $60 \%$ of the total production (Slivyak 
\& Podosenova, 2013). Further, $90 \%$ of the total hard coal production in Poland continues to come from Longwall mining. ${ }^{1}$ In Ukraine, underground mining accounts for $99 \%$ of the total coal production (Coal Mine Methane Recovery in Ukraine, 2002).

In developed countries, using advanced technologies majority of the coal is extracted by UG method except for Australia, where advanced technology and low-cost environment-friendly production method helps to increase the OC productivity (Mitra and Saydam, 2012b).

In developing countries opencast method is more popular due to high productivity, lower cost of production and application of large mining equipment. Coal production in Kazakhstan through surface mining was $73 \%$ in 1990, which increased to $89 \%$ in the year 2000 (Kazakhstani GHG Emissions Inventory from Coal Mining and Road Transportation, 2002). However, in the current times, the total extraction of coal in Kazakhstan is estimated at $85 \%$, which is retrieved through the OC method (Oprisan, 2011). Most of the mines in Brazil are opencast. $^{2}$ In China, $95 \%$ of the total coal production is extracted through the UG method. (Kishore, 2018a). Skilled human resource and advanced technology along with the investment in the underground mining sector are the reasons behind the large UG coal production in China (Kishore, 2018b) In South Africa OC and UG method contributes $49 \%$ and $51 \%$ of the total production (Munnik, 2010). Thus, the OC method of production is dominating in most of the developing countries like Kazakhstan, Brazil and India.

\section{Present Status of Coal Mining in India}

As stated above in India, coal is mined using both the methods: UG and OC method. However, the majority of the coal extracted in India is through the OC method, and it constitutes, $93.26 \%$ of the total coal production in the country (Coal Directory of India, 2016-17c). The share of the OC method of coal production has increased over the years. Less expenditure and wastage is the reason behind the dominance of $\mathrm{OC}$ mining technique. During the time of nationalisation of the coal mining industry in 1973, the total coal production was only 75 million tonnes per year, and the share of OC mining was only $20 \%$ (Ghose \& Majee, 2001a). In the FY 1998-99, the production of coal in India was 228.747 million tonnes (77.15\%) from OC mines whereas, 67.761 million tonne (22.85\%) from UG mines (Coal Directory of India, 1998-99c).

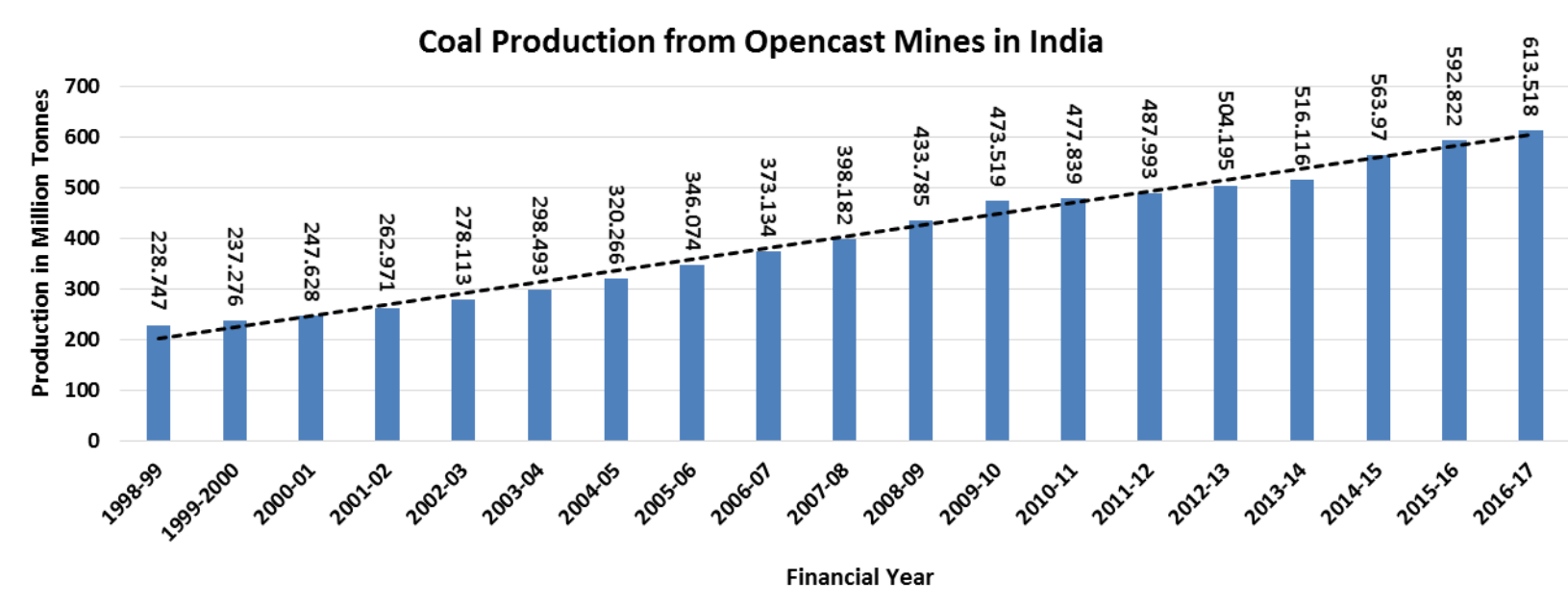

Figure 1: Coal Production from opencast mines in India (FY 1998-99 to 2016-17) Source: Coal Directory of India, FY 1998-99 to 2016-17

\footnotetext{
${ }^{1}$ Eurocoal. Available at: https://euracoal.eu/info/country-profiles/poland/ (accessed on 02 September 2018)
}

${ }^{2}$ Source: BRAZIL Market Overview: Mining Equipment and Supplies. Available at https://build.export.gov/build/ (accessed on 2 September 2018) 


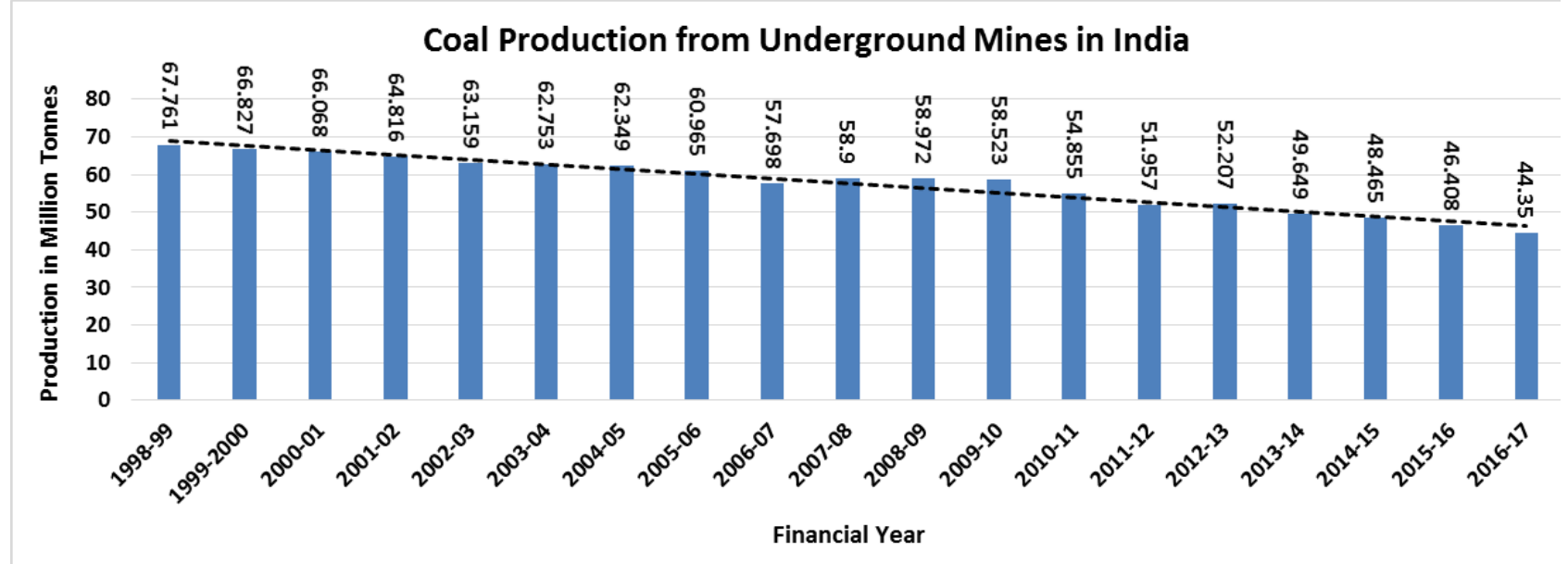

Figure 2: Coal Production from UG mines in India (FY 1998-99 to 2016-17) Source: Coal Directory of India, FY 1998-99 to 2016-17

During the FY 2007-08, the coal production through the OC method was only 398.182 million tonnes, which increased to 613.518 million tonnes with a total increase of $54.07 \%$ in the FY 2016-17 (Figure 1). Furthermore, the coal production through the UG method was only 58.90 million tonnes in the FY 2007-08, and it further, decreased to 44.350 million tonnes in the FY 2016-17 with a total $24.70 \%$ decrease. Thus, the UG method of coal production is decreasing in share, and the production through $O C$ coal mining method has increased over the years (Figures $1 \& 2$ ).

A worldwide average of coal production from OC mining is $40 \% .^{3}$ However, in India, OC method of coal mining constitute more than $90 \%$ of the total production, and the share is increasing at a faster rate over the years (Figure 3 ).
Choice of mining method depends on various factors such as geological condition (depth, size, type, and quality of deposit), technological development and level of mechanisation. Besides these factors, production cost along with selling price, environmental and social aspects are also significant that should be taken into consideration before mining. These factors indeed determine the differences between resources and reserve of coal (Zehirov, 2017a). OC method is generally chosen for shallow coal seams, while UG method is chosen for deeper coal seams. It is apparent from Figures 4 and 5, that production from the $\mathrm{OC}$ coal mines demonstrates rapid growth over the years, whereas production from the UG mines shows negative growth over the years (Figure 1).

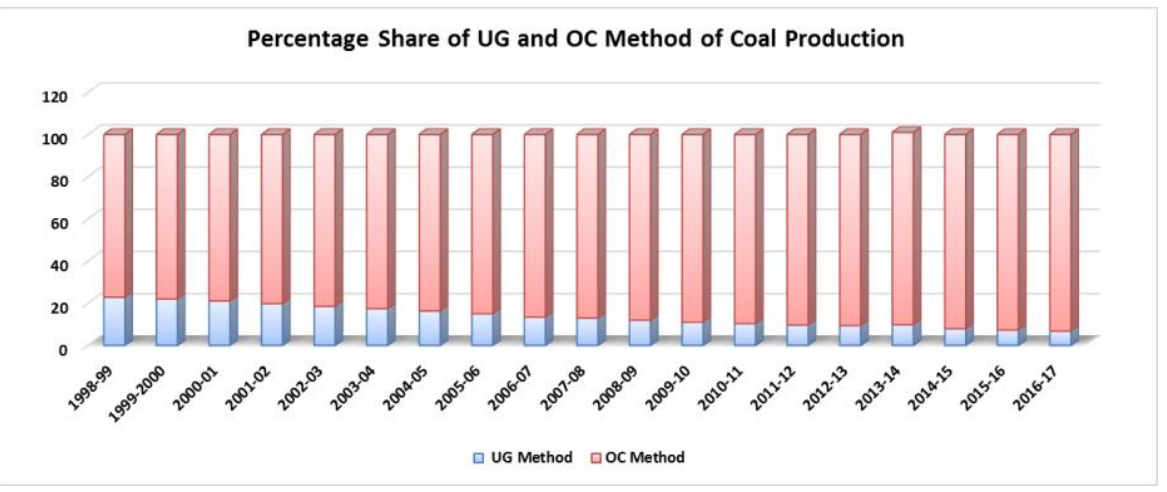

Figure 3: Percentage of a Share of OC and UG Mines in India. Source: Coal Directory of India, FY 1998-99 to 2016-17

\footnotetext{
${ }^{3}$ Will privatisation help the cause of coal industry? The Asian Age. Available at
} 


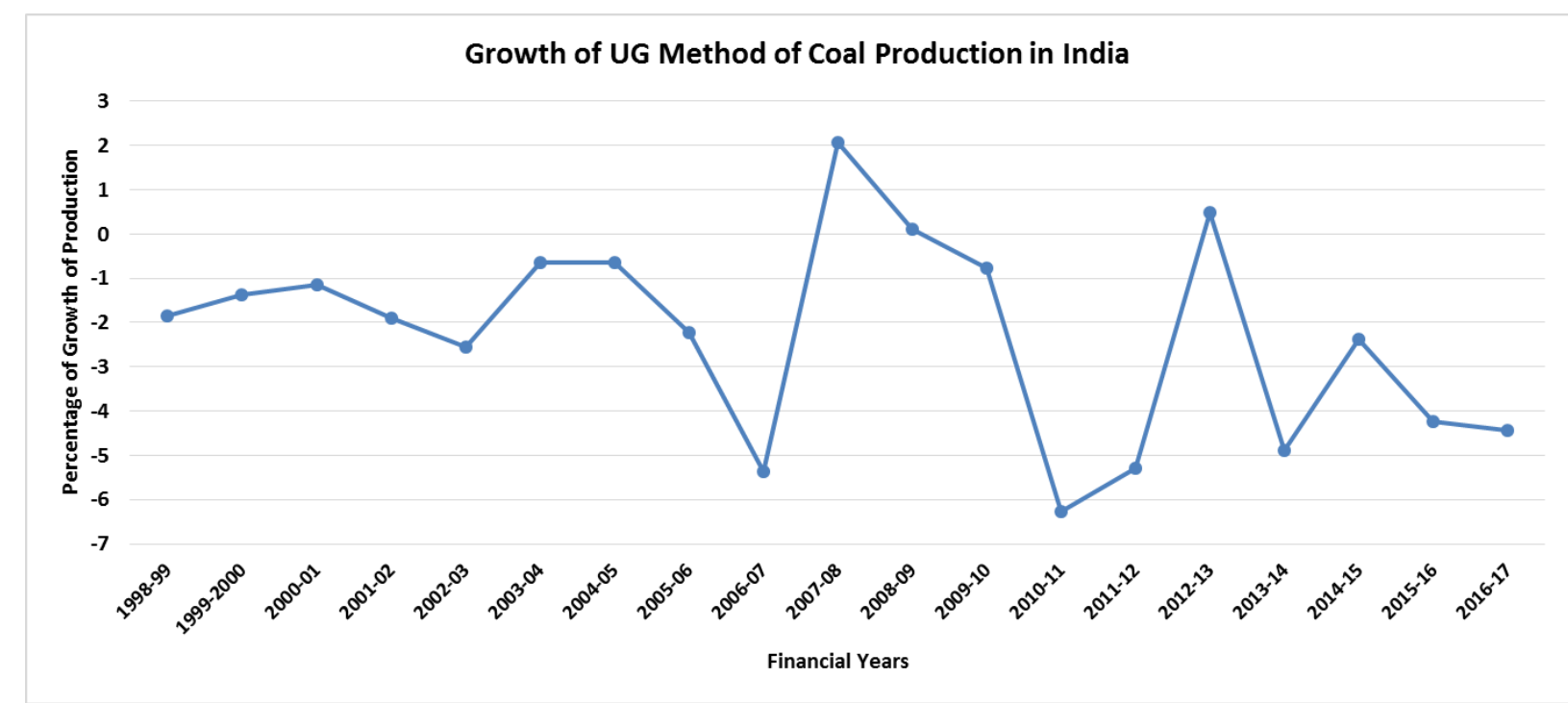

Figure 4: Percentage of Growth of UG Method of Coal Production in India. Source: Coal Directory of India, FY 1998-99 to 2016-17

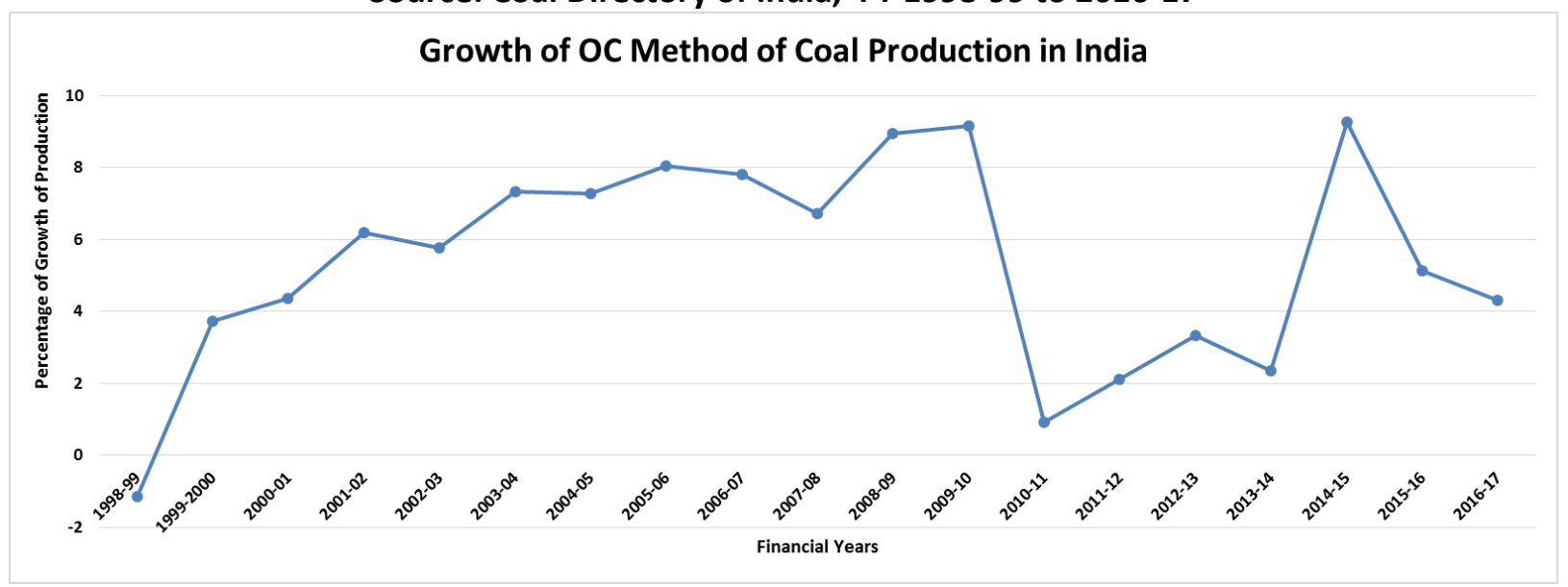

Figure 5: Percentage of Growth of OC Method of Coal Production in India. Source: Coal Directory of India, FY 1998-99 to 2016-17

Currently, India has 476 mines in operation, $93.26 \%$ of the total production (Coal India among which, 236 are UG mines, 215 are OC, Directory, 2016-17). 70\% of the total coal and 25 mines are mixed in nature (Figure 6). resource in India is extractable by UG mining However, the percentage of a number of OC method, whereas UG mines constitute less than mines is only $45.16 \%$, whereas it accounts for $10 \%$ of the overall production (Raghavan, 2014).

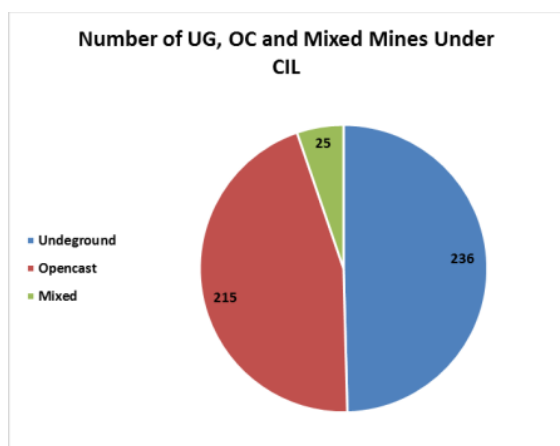

Figure 6: Type and Number of Mines under CIL. Source: Coal Directory of India, FY 2016-17 


\section{Underground Method of Coal Mining}

UG mining method is the oldest method of coal mining, where coal is extracted by making a tunnel into the earth surface. Tunnels and horizontal shafts are made in order to extract the coal. Thus, a network of tunnels is formed in the underground. As already stated, UG coal mining method is dominating over the $\mathrm{OC}$ method in the world, as more than $60 \%$ of the total coal production in the world is extracted from UG mines. However, in India, only $6.74 \%$ of the overall coal production is from UG mines (Coal Directory of India, 2016-17e).

UG mining has evolved from the pick and shovel method to the modern mechanised Longwall technology. In India, 90\% of the total UG coal production is produced by the Board and Pillar's method, and the rest is extracted by the Longwall mining method. (Mishra et al., 2013b).

Board and Pillar's method is the most common method of UG mining. In this method, a series of pillars are made to support the roof while the coal is extracted between these pillars. Board and Pillar's mining method is more suitable for shallower coal seams, where the pressure of overlying materials are low so that the pillars are able to support the roof. However, the recovery of coal is low (60\%) compared to the Longwall method (Das Sharma, 2009a).

\begin{tabular}{l|l|l|l|l|l|l|}
\hline Table 1: Production in UG Coal Production in India by Different Methods \\
\hline $\begin{array}{l}\text { Mining } \\
\text { Methods }\end{array}$ & $\begin{array}{l}\text { Conventional } \\
\text { Board and } \\
\text { Pillar's }\end{array}$ & $\begin{array}{l}\text { Mechanical } \\
\text { Board and } \\
\text { Pillar's }\end{array}$ & $\begin{array}{l}\text { Conventional } \\
\text { Longwall } \\
\text { Method }\end{array}$ & $\begin{array}{l}\text { Mechanical } \\
\text { Longwall } \\
\text { Method }\end{array}$ & $\begin{array}{l}\text { Other } \\
\text { Methods }\end{array}$ & Total \\
\hline $\begin{array}{l}\text { Production } \\
\text { in Million } \\
\text { Tonnes }\end{array}$ & 1.123 & 34.241 & 0.126 & 2.616 & 6.244 & 44.350 \\
\hline Percentage & 2.5 & 0.3 & 5.9 & 14.1 & 100 \\
\hline Source: Coal Directory of India, FY 2016-17 & 77.2 & & & \\
\hline
\end{tabular}

In Longwall mining method, self-advancing hydraulic roof supporters, coal shearing machine, and a conveyor, which is parallel to the face of coal are used to extract the coal. In this method, within a long corridor in one side, steel supporters support the roof, while the other side involves in coal cutting. With each cutting, the coal cutter is forwarded to the excavated space. After the full removal of coal, the roof is allowed to collapse.

Longwall mining method has an advantage over the Board and Pillar's method because it allows greater extraction of coal, and it also requires less human resource compared to the Board and Pillar's method. The main drawback of the Longwall mining method is that the cost for installing machinery used in Longwall method is very high, which is not feasible for small UG mines. In India, as the majority of the UG mines are small in size, so the application of Longwall mining technology is not economically profitable.

The total coal production from UG mines in India is only $79.7 \%$ by Board and Pillar's method, whereas it is $6.2 \%$ by Longwall method (Table 1 ). Thus, most of the UG mines in India operated by Board and Pillar's method have low productivity. Therefore the production from UG mining is steadily decreasing over the years compared to the $\mathrm{OC}$ mining (Figure 4).

Recently, CIL has closed 40 UG mines because these mines had failed to make profits and contributed only $10 \%$ of the total output by Coal India Limited (CIL) but employees a huge labour force (The Economic Times, March 30, 2018). Most of the UG mines in India belongs to the colonial period. Due to inadequate technology and lesser mechanisation, most of the UG mines in India operates in a traditional manner involving more labour force. 


\section{Major Advantages of Underground Coal Mining Method}

Lesser Environmental Impacts: UG mines are operated over a smaller area, and it affects a small area compared to the OC method. Thus, it causes less deforestation, less topsoil removal, lesser impact on the ecosystem of surrounding areas than the OC method. In UG mines, generation of dust is limited within the UG environment; and in the surface, it emits a lesser amount of dust compared to the OC mines. Thus, UG mines have a lesser environmental impact when compared to that of the OC method. This observation bear resonance to the observation as reported by Banerjee and Mistri (2019) in their research on the impact of Barjora colliery area of Bankura district, West Bengal on diversification of rural livelihoods. UG method is useful for densely populated areas or ecologically sensitive areas, where the extraction of coal by the OC method can seriously affect the environment. UG mining is also suitable for forest areas, where the $O C$ method requires the conversion of forest land. Thus, the environmental impact is much lower in UG mining when compared to $\mathrm{OC}$ mining.

Extraction of Deeper Coal Seams: Extraction of coal seams with greater depth is more suitable with the UG method. Rapid and large-scale extraction of shallow coal seams by OC mining method causes depletion of near-surface coal resources of India. Thus to maintain the current rate of production and to meet the future coal demand extraction of deep coal seams is necessary. Extraction of coal seams with greater depth is more suitable and economically feasible with UG mining method.

Can Avoid the Problem of Land Acquisition: UG mining method is operated over a smaller area as compared to the OC method. Thus, the land requirement in UG mining is much smaller when compared to OC mining. UG mining also has a lesser impact on the surrounding environment as it is operated within a smaller area. Thus, problems of land acquisition, displacement, etc. can be avoided through UG method. After the extraction is over, the productivity of land can be maintained through UG mining method.
Lesser Waste Generation: UG mines generates a lesser amount of waste materials compared to the OC mines. It has a lesser impact on the surface than the OC method. It does not create any anthropogenic landforms such as mine pit and mine dump like OC mining. The only deformation that takes place due to UG mining is subsidence. UG mines have a much smaller footprint on surface land as compared to the OC mines.

Involve Greater Manpower: In developing countries, UG mines involves more labour force than $\mathrm{OC}$ mines due to lesser mechanisation. As a result, it creates more job opportunities for the local people than the OC mines.

\section{Adverse Environmental impact of Underground Coal Mining Method}

UG mines affect the environment in various ways. UG coal mines are exposed to the risk of roof subsidence, mine fire, explosion, emission of toxic gases (Mkpuma et al., 2015). The impact of UG mines on the surrounding are following: changes in land use and land cover; seismicity due to blasting; emission of dust into the atmosphere, and other socio-economic problems like illegal coal mining and unsocial activities within coal mining region (Goswami, 2013a).

In the UG mines, after the extraction is over the strata is allowed to collapse, which puts a severe impact on surface topography (Wagner \& Schumann, 1991). With subsidence in subsurface, surface land also subside. Subsidence affects the surrounding structures like the ground, agricultural land, irrigation network, transport lines and others (Li et al., 2016). Land subsidence and damages of property and other infrastructures is the significant impact of UG mining.

UG coal mines also affect the groundwater of the mining area. Over exploitation of groundwater and dewatering within the UG mines affect the groundwater regime (Table 2). Subsidence of land also damaged the aquifer (Goswami, 2013b). Thus, water contained within the aquifer may penetrate deep below as a result of subsidence. Sometimes, the water that 
discharged from UG mines has high hardness due to the presence of Sulphate and Chloride, which are not suitable for drinking or bathing (Tiwary, 2001a). Thus, the quality of both surface and subsurface water gets degraded by wastewater discharged from the UG mines.

Emission of Methane gas from UG coal mines is another impact of UG mining on the environment. The deeper the mine, the higher the amount of methane emission. Methane is also responsible for underground mine fire.

UG mines are prone to accidents, and most of them take place due to two main reasons; either

\begin{tabular}{|c|c|}
\hline Activity within the UG mines & Impact \\
\hline Depillaring and Blasting. & $\begin{array}{l}\text { Land Subsidence and Damages to } \\
\text { Property and Infrastructures. }\end{array}$ \\
\hline Dewatering & Over exploitation of Groundwater. \\
\hline Subsidence in Surface and sub-surface. & Damages to the Aquifer. \\
\hline Drilling, Blasting, Loading, and Transportation. & $\begin{array}{l}\text { Pollution of Land, Water, and } \\
\text { Atmosphere. }\end{array}$ \\
\hline $\begin{array}{l}\text { Unhealthy Underground Environment and Dust } \\
\text { Generation during Blasting and Extraction. }\end{array}$ & Health Issues to Mine Workers. \\
\hline $\begin{array}{l}\text { Flooding, Subsidence, and Outgassing within the UG } \\
\text { Mines }\end{array}$ & $\begin{array}{l}\text { Accidents and Deaths of Mine } \\
\text { Workers }\end{array}$ \\
\hline
\end{tabular}

\section{Opencast Method of Coal Mining}

Choosing the appropriate mining method for extraction of coal depends on several factors, and the OC method is generally chosen when the coal deposit is large, and the seams are located near the surface. OC mining or open pit mining is a surface mining technique where overlying rock and soil materials (overburdens) are removed to extract the underlying coal strata. As, the overlying materials also called as overburden piled up near the mining site hence, overburden dump, spoil tips and other anthropogenic landforms are formed. Excavated area formed a pit, which is known as mine pit. Thus, the $O C$ mining method is liable for the change in topography. OC mining method is dominating in India because of its more accessible mode of extraction, a higher rate of production, safety concern and the higher scope for applying faulty engineering structure within tunnels or due to the exposure to flammable methane or coal dust (Das Sharma, 2009b).

Workers of UG coal mines are also exposed to the risk of lungs disease due to the exposure to underground coal dust. A study by Bhelkar et al., (2015a) shows that the moribund condition is prevalent more in UG coal mines (65.7\%) when compared to OC mines (54.4\%). Their study also reveals that coal miners in UG mines also open to the risk of various respiratory diseases, and backache, skin disease, tuberculosis and others.
Property and Infrastructures.

Over exploitation of Groundwater.

Pollution of Land, Water, and Atmosphere.

Accidents and Deaths of Mine Workers modern technology for augmented production (Ghose \& Majee, 2001b).

OC mines are operated over a larger area, and it uses modern, efficient and large equipment like overburden is removed by draglines, power shovels, bucket wheel excavators and conveyors are also used in this regard. Large trucks are used for the transportation of coal. Other equipment includes pick-up cars, site-mixing truck, bulldozers, scrapers, graders, water spray trucks and others. Loose and less resistant overburden is removed using bucket wheel excavators (Das Sharma, 2009c).

An essential aspect of $\mathrm{OC}$ mining is that the cost associated with the removal of overburden, which determines the profit of the mines. The depth of coal seams controls the amount of overburden to be removed. Coal seams with the greater depth require to remove a large amount of overburden, and the production cost of coal 
are higher. Nature of overburden is also crucial because hard and resistant overburden (for example, boulders,) requires blasting using efficient technology, which further increases the production cost. Here, the concept of Stripping Ratio is critical. Stripping Ratio is calculated in the following way:-
Stripping Ratio = Unit Waste/ Unit ore cost of stripping overburden (Coal Directory of India, 2016-17f)

Higher stripping ratio indicates a higher cost for overburden removal. Stripping Ratio for OC mines in India is increasing at a faster rate, and with the increasing Stripping Ratio, the production cost has also been increasing for the OC mines (Coal Vision, 2030c).

\begin{tabular}{|c|c|c|c|}
\hline Company Name & $\begin{array}{l}\text { Overburden Removal } \\
\text { (million tonnes) }\end{array}$ & $\begin{array}{l}\text { Production (million } \\
\text { tonnes) }\end{array}$ & Stripping Ratio \\
\hline $\begin{array}{l}\text { Eastern Coalfields } \\
\text { Limited }\end{array}$ & 124.637 & 32.390 & 3.85 \\
\hline $\begin{array}{l}\text { Bharat Coking Coal } \\
\text { Limited }\end{array}$ & 131.215 & 35.358 & 3.71 \\
\hline $\begin{array}{l}\text { Central Coalfields } \\
\text { Limited }\end{array}$ & 102.630 & 66.310 & 1.55 \\
\hline $\begin{array}{l}\text { Northern Coalfields } \\
\text { Limited }\end{array}$ & 324.136 & 84.096 & 3.85 \\
\hline $\begin{array}{l}\text { Western Coalfields } \\
\text { Limited }\end{array}$ & 166.142 & 40.264 & 4.13 \\
\hline $\begin{array}{l}\text { South Eastern } \\
\text { Coalfield Limited }\end{array}$ & 174.588 & 120.131 & 1.45 \\
\hline $\begin{array}{l}\text { Mahanadi Coalfields } \\
\text { Limited }\end{array}$ & 123.342 & 138.193 & 0.89 \\
\hline $\begin{array}{l}\text { North Eastern } \\
\text { Coalfields }\end{array}$ & 5.676 & 0.597 & 9.51 \\
\hline $\begin{array}{l}\text { Total Coal India } \\
\text { Limited } \\
\end{array}$ & 1156.569 & 522.663 & 2.21 \\
\hline $\begin{array}{l}\text { Singareni Collieries } \\
\text { Company Limited } \\
\end{array}$ & 312.636 & 51.821 & 6.03 \\
\hline Others Public & 23.779 & 9.45 & 2.51 \\
\hline Private & 124.394 & 29.584 & 4.56 \\
\hline India & 1617.378 & 613.518 & 2.65 \\
\hline
\end{tabular}

Stripping ratio of 2:1 to $4: 1$ is very common in the mines while the stripping ratio greater than $6: 1$ makes the extraction unprofitable depending on the ore extracted (Das Sharma, 2009d). From Table 3, it is seen that the stripping ratio of India is 2.67 for the year 2016-17, whereas in the FY 1998-99 it was 2.09. This indicates that the stripping ratio is gradually increasing over the years. Stripping ratio is also high for Eastern Coalfield Limited (3.85), Bharat Coking Coal
Limited (3.71), Northern Coalfield Limited (3.85), Western Coalfield Limited (4.13), The Singareni Collieries Company Limited (6.03). This indicates that cost for extraction of coal is high within these subsidiaries of CIL and SCCL. As more the near surface coal resources will be depleted, the stripping ratio will increase in future to extract the deeper coal seams. Thus, waste generation will also increase in future, and after a certain 
level, higher stripping ratio will make the extraction unprofitable.

Output Per Man shift (OMS) is another measure which is used to measure the efficiency and productivity of mine or particular mining method. It gives an idea about the efficiency and feasibility of a particular mining method (Coal Directory of India, 2016-17g). This is the simple ratio between input and output of mines). The higher value of OMS indicates the efficiency of mine, whereas the lower value indicates the unprofitable condition in mines. From Figure 6, it is seen that the OMS under CIL for OC mines increases from 5.52 in FY 1998-99 to 15.00 in FY 2016-17 with a three-fold increase, whereas for UG mines, OMS shows prolonged growth: 0.59 in FY 1998-99 into 0.8 in FY 2016-17 (Figure 6).
OMS for SCCL also shows a similar result, OMS for OC mines under SCCL was only 3.92 in FY1998-99, whereas in FY 2016-17 it is 13.85 as compared to the UG mines, which stands at 0.75 in FY 1998-99 to 1.1 in FY 2016-17. Thus, the productivity and efficiency of UG mines are much lower than the $O C$ mines, and the technology or efficiency of UG mines does not show any significant progress. Low OMS for UC mines is due to constraints in size, human resource, and technology within the UG mines.

Indeed, OC mines have more efficient technology and higher productivity than the UG mines. Thus, the share of production of $\mathrm{OC}$ mines is increasing over the years, whereas the share of UG production shows a decreasing trend (Figures 4 and 5).

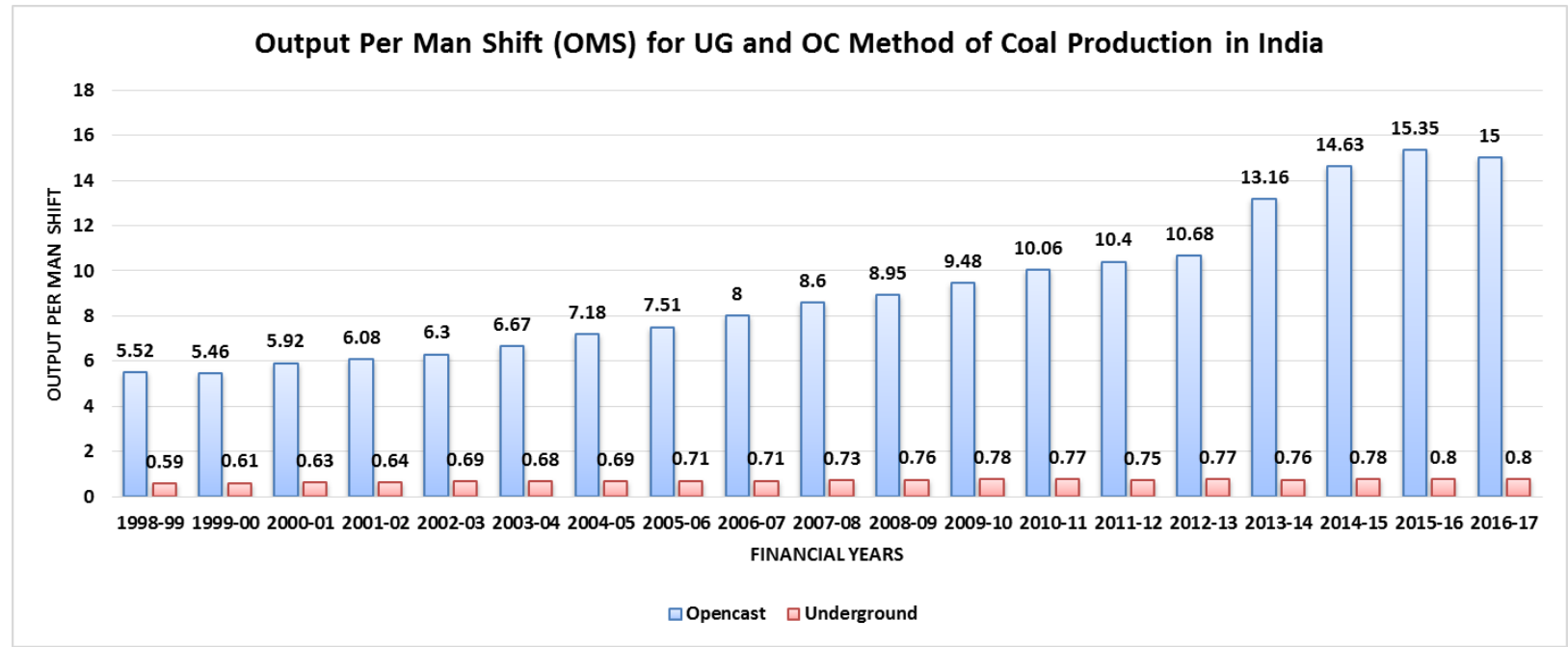

Figure 6: Output Per Man Shift (OMS) of UG and OC mining methods under CIL. Source: Coal Directory of India (FY1998-99 to 2016-17)

Advantages of Opencast Method of Coal Mining

Extraction of coal over a large area: OC mining method is useful for extraction of shallow coal seams that spread over horizontally and situated over a larger area. Removal of overlying materials exposed the underlying coal seams and helped to extract the underlying coal strata. Therefore, it recovers a more significant amount of coal than UG method.

Less wastage: Wastage of coal is less in the OC method as compared to the UG method. In UG mining method, the amount of coal wastage is high during blasting, excavation, extraction, transportation within the mines, whereas, in OC mines, full exposure of the coal seams and application of modern and sophisticated mining techniques reduces the amount of coal wastage.

The benefit of using modern and large machinery: OC mines provides more enormous scope for applying modern, large and efficient machinery, which saves the labour cost and time. Due to the full exposure of coal strata, installation and operating the machinery is natural in OC mines when compared to the UG mines. Equipment used in UG mines are expensive and can be used only for mining, whereas OC mining equipment can also be used for building construction (Yamatomi \& Okubo, 
2009). With modern equipment productivity and production cost is less in OC mines as compare to UG mines. Blasting, excavation, extraction, and transportation of coal are rather easy in $\mathrm{OC}$ mines, as it is operated above ground.

Less production cost of coal compared to the UG mining: UG mining method is more expensive than the $\mathrm{OC}$ method. Use of large and heavy machinery helps to recover a more considerable amount of coal in OC Mines. As a result, the production cost is much low in the $O C$ method as compared to UG mining.

Lesser Risk of Accidents: OC mines have a lesser risk of accidents as compared to the UG mines. OC mining has a less hazardous environment for workers (Zehirov, 2017b).

\section{Adverse Environmental Impact of Opencast Coal Mining}

Though the OC method of coal mining is more economical than UG method, OC coal mines have a more significant impact on the environment than UG mines. OC mines are responsible for environmental degradation. OC mines destroyed the land and associated ecosystem, forest, displaced people and affected the environment (Garada, 2015). Destruction of forest and agricultural land, discharge of wastewater are the main adverse impacts of OC mining on the environment. (Chitade \& Katyar, 2010). Discharge of wastewater and pollutants changes the habitat pattern and leads to change in the soil, air, and water quality (Baruah et al., 2016).

The problem of land acquisition is much more prevalent in $O C$ mines. As the $O C$ mines developed over a larger area, therefore it acquires much more land than the UG mines. OC mines required more space than UG mines for the parking of the heavy vehicles, transportation, dumping, storing the coal. Land in OC mines is also used for staff residences, official buildings, workshops and other mundane purposes. Furthermore, a buffer area of empty spaces should be maintained outside the OC mines in order to prevent the environmental degradations like spreading of dust, reducing the impact of blasting, construction of catchment drains, sediments walls and others. Thus, the problem of land acquisition creates many complexities for the $\mathrm{OC}$ mines.

The topography of the mining site is also changed through the process of $\mathrm{OC}$ coal mining; as the formation of artificial landforms like mine pits, overburden dump changes the relief, altitude, and slope of the mining site. With these changes in the mining site, natural geomorphic processes also change. Landscape change and formation of anthropogenic landforms is the most devastating impact of $O C$ coal mining. OC mining method not only disrupts the natural topography, but it also alters the natural geomorphic processes of erosion and sedimentation.

The problem of land degradation is another major impact of OC mines. After the extraction is over or in certain situations, if the near surface coal seams are exploited, the OC mines are abandoned. However, in abandoned OC mines, the mining sites are left without backfilling or restoring the topography of the mining site. Thus, the land lost its productivity and leads to land degradation (Table 4).

Currently, OC coal mining is responsible for land degradation due to massive waste generation at a very fast rate, and this indicates that backfilling the $\mathrm{OC}$ mines is necessary and very important. However, presently no such steps have been taken for backfilling the $\mathrm{OC}$ mines.

Mine water from OC mine generally contains a high level of total suspended solids, total dissolve solids, heavy metals, hardness, Sulphate, oil, grease, Nitrate and pollute the water regime if it is discharged without proper treatment. (Tiwary, 2001b). Wastewater discharged from the OC mines degrade the quality of both surface and sub-surface water. 


\begin{tabular}{|c|c|c|}
\hline $\begin{array}{l}\text { Type of } \\
\text { Impacts }\end{array}$ & Activity within OC Mine & Adverse Impacts \\
\hline \multirow{5}{*}{$\begin{array}{l}\text { Impact on } \\
\text { Land }\end{array}$} & Excavation and dumping. & Alteration of topography \\
\hline & $\begin{array}{l}\text { Closure of OC mine without proper } \\
\text { restoration of topography. }\end{array}$ & $\begin{array}{l}\text { Land Degradation and land use, land cover } \\
\text { change. }\end{array}$ \\
\hline & Excavation and dumping. & Removal of topsoil. \\
\hline & Spreading of pollutants from mine. & Contamination of soil. \\
\hline & Excavation and dumping. & Deforestation. \\
\hline \multirow[t]{4}{*}{$\begin{array}{l}\text { Impact on } \\
\text { Water }\end{array}$} & Excavation and dumping. & $\begin{array}{l}\text { Degeneration of rivers and alteration of } \\
\text { geomorphic properties of watersheds. }\end{array}$ \\
\hline & $\begin{array}{l}\text { Discharge of wastewater and runoff } \\
\text { from the mine during rainfall. }\end{array}$ & $\begin{array}{l}\text { Acid mine drainage and contamination of } \\
\text { surface and sub-surface water. }\end{array}$ \\
\hline & Erosion of mine dump. & Sedimentation within the river bed. \\
\hline & $\begin{array}{l}\text { Dewatering within the mine and } \\
\text { overexploitation of groundwater. }\end{array}$ & Lowering the groundwater table. \\
\hline \multirow[t]{2}{*}{$\begin{array}{l}\text { Impact on } \\
\text { Air }\end{array}$} & $\begin{array}{l}\text { Blasting, drilling, excavation, } \\
\text { transportation etc. }\end{array}$ & $\begin{array}{l}\text { Generation of dust, reduction of the } \\
\text { visibility, particularly in the winter season. }\end{array}$ \\
\hline & $\begin{array}{l}\text { Blasting, drilling, excavation, and } \\
\text { dumping. }\end{array}$ & $\begin{array}{l}\text { Emission of gases and other pollutants in } \\
\text { the atmosphere. }\end{array}$ \\
\hline $\begin{array}{l}\text { Impact on } \\
\text { the } \\
\text { Ecosystem }\end{array}$ & $\begin{array}{l}\text { Excavation and dumping and related } \\
\text { landscape alteration. }\end{array}$ & $\begin{array}{l}\text { Destruction of local ecosystem and habitat } \\
\text { of species. }\end{array}$ \\
\hline \multirow{5}{*}{$\begin{array}{l}\text { Socio- } \\
\text { Economic } \\
\text { Impact }\end{array}$} & $\begin{array}{l}\text { Blasting, drilling, excavation, } \\
\text { transportation etc. }\end{array}$ & Noise pollution \\
\hline & Excavation and dumping. & Destruction of agricultural land. \\
\hline & Excavation and dumping. & $\begin{array}{l}\text { Displacement of people and land loss, } \\
\text { damages of infrastructures, social } \\
\text { instability, and unrest. }\end{array}$ \\
\hline & Dust generation and pollution. & $\begin{array}{l}\text { Health issues of local people and mine } \\
\text { workers. }\end{array}$ \\
\hline & Blasting. & Damages of infrastructures. \\
\hline
\end{tabular}

Blasting, waste removal, extraction, Dust particles also reduce visibility and put a transportation generates a large amount of dust negative impact on the surroundings. People in $O C$ mining areas. Agricultural land, living in the $O C$ mining areas are suffering from households, institutions, roads, water bodies lungs diseases like tuberculosis (Bhelkar et al., etc. are surrounded by dust from the OC mines. 2015b). 


\section{Conclusion}

Mining of coal in India started from the colonial period, and after the independence of India, there is a great reluctance among the government to renovate the coal mining industry. Due to lack of infrastructure and technological constraints, extraction of coal seams with greater depth is not possible always. UG mining is more appropriate techniques for coal seams with greater depth. However, in the present scenario, the UG mining methods constitute only a small portion $16.74 \%$ in 2016 17) of overall coal production in India. Mining authorities, whether public or private sector is emphasising on OC mining technique, which is more economical mining method. However, 57\% of the CIL extractable coal resource is situated in the forest areas, where regulatory approvals may get more regulated in future and making it challenging to open OC mines in forest areas (Fernandes \& Sanzillo, 2013b).

Over-extraction of surface coal seams by OC method of mining will exhaust the near surface coal seams in future. Moreover, to reduce the production cost, environmental aspects and sustainable measures were neglected in the arena of $\mathrm{OC}$ mining. Thus, $\mathrm{OC}$ mining is degrading the environment in various part of the country. Due to the unprofitable condition and lack of modern technology, environmental impacts by OC mines in India is much higher when compared to the other countries. Allowing the private sector in the $\mathrm{OC}$ mining sector is making the situation more complicated. Private $O C$ mines are more concerned with profit rather than taking environmental measures. OC mines in India should be more concerned with environmental impacts. Therefore, provision of sediment wall, catchment drains to entrap sediments, afforestation programme, backfilling of mines, processing of wastewater, dust suppression from wastewater and minimising the impacts on land, water and ecosystem are much required in OC mines of India. OC mining authorities in India should promote sustainable mining measures.

Extraction of deeper coal seams with $\mathrm{OC}$ mining method may not be feasible due to the higher
Stripping Ratio. Thus, in order to maintain the current rate of production, and to meet the demand for coal in the future, more emphasis should be given on UG mining. Introduction of modern technology and efficient equipment is much needed in UG mining. Therefore, application of Longwall mining can help to increase the production from UG mines, and it will also help to reduce the production cost. Longwall mining technique has an advantage over the traditional Board and Pillar's method because it has facilities for more recovery of coal in the strata and helps to increase productivity.

Half of the total production of Coal India Limited (CIL) is from 15 mines which are OC mines and other 452 mines constitute $50 \%$ of the total production (Coal Vision, 2030d). Thus small scale mining operation does not become feasible for modernisation. In respect of UG mines, $87 \%$ among them are either semi-mechanised or operated in a old-fashioned (manual) way (Coal Vision, 2030e).

In the FY 2010-11, the Geological Survey of India (GSI) has explored a total of 115 seams, among which 79 seams lie below the depth of 150 metres, and 43 seams are below 300 metres depth. Therefore, UG mining is more efficient to extract these seams. However, UG mining have higher production cost and lower productivity as it extracts only $40-70 \%$ of the coal deposit. Thus, extraction of deeper coal seams can increase the production cost and market price of coal. The price of electricity can also increase with that. Thus, current coal price in India does not permit for UG mining (Fernandes \& Sanzillo, 2013c). Thus, small and unprofitable mines should merge to make bigger and profit gaining mines. Investment is much required in UG mines to promote modern technology and increase production. Ignoring the UG mining sector may affect the future coal production in India, as in future when near-surface coal resource is depleted or extraction is carried through OC method will be unprofitable due to higher stripping ratio, adopting UG mining will be the solution. However, in the present scenario, most of the UG mines are closing every year and the UG production shows a declining trend. Thus, 
investment and the opening of new UG mines are much needed, keeping in view the future coal demand. Allowing private sectors in the UG mining sector may be a right solution, as the private sector will provide investment and technology for the UG mines and UG mines will help to sustain the future coal production of India.

Increasing the import of coal from the other countries is not a solution to meet the rising coal demand of India. If coal import increases, the domestic coal sector may face intense competition in future. Increasing the import will also affect the Gross Domestic Product (GDP) and the economy of India.

In India, selling of raw coal is done by either through E-auction or through Long-term Fuel Supply agreement (FSA). Price of Raw coal which sold under FSAs by CIL is not always reflecting the market price of the coal in the international market, while the coal sold under E-Auction reflect the market price. Therefore, the price of coal sold under FSAs is much lower than the coal sold under E-auction (Mishra \& Suhag, 2017). Price of coal should be determined to keep in view the international price of coal. Giving subsidies in coal price only cannot save this sector.

Generation of electricity consumes nearly $75 \%$ of domestic coal production (Chikkatur, 2008b). Energy demand will increase in the future due to population growth, industrial expansion, and infrastructural development. Exploration effort by $\mathrm{CIL}$ is inadequate keeping in view the future coal demand (Fernandes \& Sanzillo, 2013d). Demand for electricity and coal is so high in the country that the coal mines are violating environmental regulation and norms. Therefore, the main challenge before the government is to enforce and tighten the existing regulations. (Chikkatur, 2008c).

Coal conservation and finding alternatives to coal in the energy sector is much required. Dependence on coal not only degraded the environment, but it also affects the economy as the coal import of India is rising over the years. Thus, more emphasis should be given to nonconventional energy sources like solar energy, wind energy, and atomic power etc. Instead of heavy dependence on coal government should take the initiative to popularise the nonconventional and eco-friendly sources of energy. Conservation measures of coal should also be taken keeping in view the future coal demand of India. Saving electricity and energy, increasing the use of nonconventional sources of energy is required in this regard. Also, lower grade coal should be mixed with superior quality coal for use in industries. Furthermore, coal wastage should be reduced during transportation. Coal is a resource of our country, and we have to realise rather than understand the value of coal keeping in view the future coal demand of India and by this way conservation of this precious resource is possible.

\section{References}

Aggarwal, Y. (2018). Will Privatisation Help the Cause of Coal Industry?. The Asian Age. From https://www.asianage.com/opinion/oped/2702 18/will-privatisation-help-the-cause-of-coalindustry.html.

Baruah, J., Baruah, B. K., Kalita, S. \& Choudhury, S. K. (2016). Impact Analysis of Open Cast Coal Mining on Land Use/Land Cover using Remote Sensing and GIS Technique in Ledo Margherita Region of Assam, India. Imperial Journal of Interdisciplinary Research (IJIR), Vol-2, Issue-8, 2016.

Banerjee, R., \& Mistri, D. B. (2019). Impact of Coal Mining in Diversification of Rural Livelihoods: A Case Study in the Barjora Colliery Area of Bankura District, West Bengal. Journal Space and Culture, India, 6(5), 228-240. From https://doi.org/10.20896/saci.v6i5.335.

Bhelkar, S. M., Ughade, S. N., Thakre, S. \& Jogdand, G. (2015). A Comparative Study of Morbid Conditions Amongs OC and UG Coal Miners. Journal of Evolution of Medical and Dental Sciences 2015; Vol. 4, Issue 07, January 22. DOI: $10.14260 /$ jemds/2015/159. Pp.11321137.

BRAZIL Market Overview: Mining Equipment and Supplies. From https://build.export.gov/build/idcplg?ldcService =DOWNLOAD_PUBLIC... 
CIL Looks to Offer Coal at Prices Lower Than Private Operators - The Economic Times. (Mar 30, 2018, 11.23 PM IST). From

https://economictimes.indiatimes.com/industry /indl-goods/svs/metals-mining/cil-looks-tooffer-coal-at-prices-lower-than-privateoperators/articleshow/63550479.cms.

Chikkatur, A. P. (2008). A Resource and Technology Assessment of Coal Utilization in India. Coal Initiative Reports, White Paper Series. Pew Center on Global Climate Change, 2101 Wilson Boulevard, Suite 550, Arlington, VA 22201.

Chitade, A. Z. \& Katyar, S. K. (2010). Impact Analysis of Opencast Coal Mines on Land Use/ Land Cover using Remote Sensing and GIS Technique: A Case Study. International Journal of Engineering Science and Technology. Vol. 2 (12), 2010, Pp.7171-7176.

Coal Directory of India. (FY 1998-99 to 2016-17). Government Of India, Ministry Of Coal, Coal Controller's Organisation Kolkata 1, Council House Street Kolkata - 700 001. From http://www.coalcontroller.gov.in/pages/display /16-coal-directory.

Coal Vision 2030. (2018). Stakeholders' Consultation. Coal India Limited. From https://www.coalindia.in/DesktopModules/Doc umentList/documents/Coal_Vision_2030_docu ment_for_Coal_Sector_Stakeholders_Consultati on_27012018.pdf.

Coal Mining in the United States. (2018). In Monitoring and Sampling Approaches to Assess Underground Coal Mine Dust Exposures. National Academies of Sciences, Engineering, and Medicine. 2018, Washington, DC, The National Academies Press. From https://www.ncbi.nlm.nih.gov/books/NBK5318 $61 /$.

Coal Mine Methane Recovery in Ukraine: Inventory of Methane Emissions from Coal Mines in Ukraine: 1990-2001. (2002). Prepared by: Partnership for Energy and Environmental Reform. From https://www.epa.gov/sites/production/files/20 16-04/documents/inventory2002.pdf.
Das Sharma, P. (2009). Coal and Metal Surface and Underground Mining - An Overview. From https://miningandblasting. files.wordpress.com/ 2009/09/coal_and_metal_surface_and_undergr ound_mining_an_overview.pdf

Energy Statistics. (2017). Ministry of Statistics and Programme Implementation Government of India. Central Statistics Office, New Delhi. From http://www.mospi.nic.in/sites/default/files/pub lication_reports/Energy_Statistics_2017r.pdf.pd $f$.

Eurocoal: The voice of Coal in Europe. From https://euracoal.eu/info/countryprofiles/poland/

Fernandes, A. \& Sanzillo, T. (2013). Coal India Running on Empty? Greenpeace India. From https://www.banktrack.org/download/coal_ind ia_running_on_empty_/coalindiarunningonemp ty.pdf.

Ghose, M. K. \& Majee, S. R. (2001). Air Pollution Due to OC Coal Mining and It's Control in Indian Context. Journal of Scientific \& Industrial Research. Vol -60, October: 2001, Pp.786-797.

Garada, R. (2015). Coal Mining Environment and Health Problems: A Case of MCL Affected Households at Talcher, Odisha (India). IOSR Journal of Humanities and Social Science (IOSRJHSS), Volume 20, Issue 5, Ver. 1 (May. 2015), Pp. 89-98.

Goswami, S. (2013). Coal Mining, Environment and Contemporary Indian Society. Global Journal of Human Social Science Geography, Geo-Sciences, Environmental Disaster Management. Volume 13 Issue 6 Version 1.0 Year 2013. ISSN: 0975-587X.

Indian Coal \& Lignite Resources-2017. (2017). Natural Energy Resources Mission-IIB.

Government of India, Geological Survey of India. From

https://gsi.gov.in/cs/groups/public/documents/ document/b3zp/mtyx/ edisp/dcport1gsigovi16 1863.pdf.

Kazakhstani GHG Emissions Inventory from Coal Mining and Road Transportation. Final Project Report (2002). Kazakh Research Institute for 
Environment Monitoring and Climate. Seifullin Av. 480072 Almaty Kazakhstan. From http://www.globalchange.umd.edu/data/aisu/p ublications/kazakemm.pdf.

Kishore, B. (2018). Future of Bulk Production from Underground Coal Mine in India. Coal Mining Technology \& Management Vol. 21, No. 1 - June 2018. Indian Institute of Coal Management Kanke, Ranchi - 834006. From www.iicm.ac.in/images/pdf/CMTM-JUNE2018.pdf

Li, J., Zhang, T. T., Yang, W. \& Zhang, Y. (2016). The Environmental Impact of Mining and Its Countermeasures. MATEC Web of Conferences 63, 04010 (2016). DOI:

10.1051/matecconf/2016630.

Mishra, D. P., Sugla, M. \& Singha, P. (2013). Productivity Improvement in Underground Coal Mines - A Case Study. Journal of Sustainable Mining. Vol. 12 (2013), No. 3. Pp. 48-53.

Mishra, P. \& Suhag, R. (2017). PRS Legislative Research. Demand for Grants 2017-18 Analysis (Coal). PRS Legislative Research. Institute for Policy Research Studies 3rd Floor, Gandharva Mahavidyalaya ,212, Deen Dayal Upadhyaya Marg, New Delhi-110002 . From http://www.prsindia.org/administrator/uploads /general/1519280783 DFG\%20analysis\%20Co al.pdf

Mitra, R. \& Saydam, S. (2012). Surface Coal Mining Methods in Australia, Mining Methods, Prof. Turgay Onargan (Ed.), ISBN: 978-953-510289-2, InTech, From http://www.intechopen.com/books/miningmethods/surface-coal-mining-methods-inaustralia

Mkpuma, R. O., Okeke, O.C. \& Abraham, E. M. (2015). Environmental Problems of Surface and UG Mining: a Review. The International Journal Of Engineering And Science (IJES), Volume 4, Issue:12,Pp. 12-20.

Munnik, V. (2010). The Social and Environmental Consequences of Coal Mining in South Africa: A Case Study. A joint initiative of Environmental Monitoring Group, Cape Town, South Africa and Both Ends, Amsterdam, The
Netherlands. From

https://www.bothends.org/uploaded_files/uplo adlibraryitem/1case_study_South_Africa_updat ed.pdf.

Oprisan, M. (2011). Prospects for Coal and Clean Coal Technologies in Kazakhstan. IEA Clean Coal Centre. From https://www.usea.org/sites/default/files/12201 1_Prospects\%20for\%20coal\%20and\%20clean\% 20coal\%20technologies\%20in\%20Kazakhstan_c cc192.pdf.

Raghavan, V., Ariff, S. \& Kumar, P. P. (2014). Optimum Utilisation of Continuous Miner for Improving Production in Underground Coal Mines. International Journal of Scientific and Research Publications, Volume 4, Issue 10, October 2014. ISSN 2250-3153.

Slivyak, V. \& Podosenova, O. (2013). Russian Coal Industry: Environmental and Public Health Impacts and Regional Development Prospects. From https://below2c.files.wordpress.com/2013/06/r ussian-coal-industry-preliminary-englishversion.pdf

Tongia, R. (2016). Report on Brookings India Roundtable on "Future of Coal-2020. Brookings India. From https://www.brookings.edu/research/reportbrookings-india-roundtable-on-future-of-coal2020/.

Tiwary, R. K. (2001). Environmental Impact of Coal Mining on Water Regime and Its Management. Water, Air, and Soil Pollution. November 2001, Volume 132, Issue 1-2. Pp. 185-199.

The Coal Resource: A Comprehensive Overview of Coal. (2009). World Coal Institute, Cambridge House, 180 Upper Richmond Road, Putney, London SW15 2SH, UK. From

https://www.worldcoal.org/file_validate.php?fil e=coal_resource_overview_of_coal_report(03_ 06_2009).pdf.

Wagner, H \& Schumann, E.H.R. (1991). Surface effects of total coal-seam extraction by UG mining methods. Journal of The South African 
Institute Of Mining And Metallurgy. Vol: 91, No. 7. Jut 1991. Pp. 221-231.

Yamatomi, J. \& Okubo, S. (2009). Surface Mining Methods and Equipment. Civil Engineering - Vol. II. In Civil Engineering Volume II. Edited by Kiyoshi Horikawa, Qizhong Guo. Enclycopedia of Life Support System, United Nations Educational, Scientific and Cultural Organization. Pp.: 155-170. From http://www.eolss.net/sample-chapters/c05/e637-06-01.pdf

Zehirov, S., Kaykov, D. \& Koprev, I. (2017). A Review of Combining Open-Pit and Underground Mining Methods around the World. Journal of Mining and Geological Sciences, Vol. 60, Part II, Mining, Technology and Mineral Processing, 2017. Pp.17-20.

\section{Acknowledgements}

Both the authors are thankful to the anonymous reviewers for their contributions and valuable comments. Authors are also thankful to the editor of the Journal of Space and Culture, India for his/ her co-operation and guidance for publishing the paper.

\section{About the Authors}

Sourav Mukherjee has completed his Masters' in Geography from the Department of Geography, The University of Burdwan. Presently, he is a Research Scholar (UGC-SRF) in the same Department. His foremost research interests are the fields of Geomorphology (Fluvial), Environment (hazards), and Application of Remote Sensing and GIS. He has published four research papers and one book chapter; and presented ten papers in National and International Seminars and Conferences.

Dr Deb Prakash Pahari is the Scientific officer, Department of Geography, The University of Burdwan. He completed B.Sc in Geography (Specialisation: Cartography), M.Sc. in Geography \& Environment Management (Specialisation: Coastal Geomorphology), and PhD (Research Topic: Coastal Resort of West Bengal and Environmental Appraisal). His foremost research interests are Geomorphology (coastal), Environment (hazards), Tourism and Remote Sensing and GIS. He completed 4 (four) research projects as a co-investigator. He has published seven research articles in scholarly books and reputed journals; and presented 18 papers in National and International Seminars and Conferences. 